看 Columbia Business School

608 in Accounting and Security Analysis

\title{
Accounting for Intangible Assets: There is Also an Income Statement
}




\section{Center for Excellence in Accounting \& Security Analysis}

Columbia Business School established the Center for Excellence in Accounting and Security Analysis in 2003 under the direction of Professors Trevor Harris and Stephen Penman. The Center ("CEASA") aims to be a leading voice for independent, practical solutions for financial reporting and security analysis, promoting financial reporting that reflects economic reality and encouraging investment practices that communicate sound valuations.

CEASA's mission is to develop workable solutions to issues in financial reporting and accounting policy; produce a core set of principles for equity analysis; collect and synthesize best thinking and best practices; disseminate ideas to regulators, analysts, investors, accountants and management; and promote sound research on relevant issues. Drawing on the wisdom of leading experts in academia, industry and government, the Center produces sound research and identifies best practices on relevant issues. CEASA's guiding criterion is to serve the public interest by supporting the integrity of financial reporting and the efficiency of capital markets.

Located in a leading university with a mandate for independent research, CEASA is positioned to lead a discussion of issues, with an emphasis on sound conceptual thinking and without obstacles of constituency positions.

More information and access to current research is available on our website at http://www.gsb.columbia.edu/ceasa

The Center is supported by our generous sponsors: General Electric, IBM and Morgan Stanley. We gratefully acknowledge the support of these organizations that recognize the need for this center. 


\section{Accounting for Intangible Assets: There is Also an Income Statement}

Stephen H. Penman; George O. May Professor, Columbia Business School

June 2009

This paper will be published in a forthcoming issue of $A$ bacus.

This paper does not necessarily reflect the views of the Center's Advisory Board or the Center's sponsors. 


\section{Table of Contents}

OVERVIEW .................................................................................................................................................

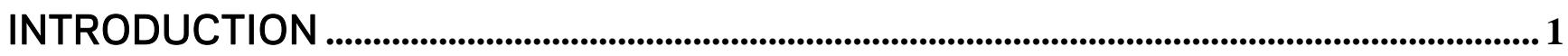

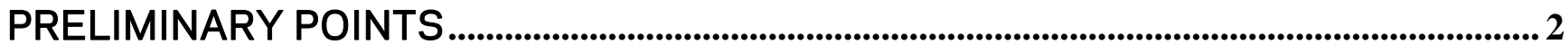

MAIN POINT: THERE IS ALSO AN INCOME STATEMENT ..............................................4

THE INCOME STATEMENT MITIGATES POOR BALANCE SHEETS ................................6

CAN THE BALANCE SHEET MITIGATE POOR INCOME STATEMENTS? .......................8

HANDLING INTANGIBLE ASSETS WITH ACCOUNTING INFORMATION ..................... 12

A. MICROSOFT CORPORATION.............................................................................................................................. 12

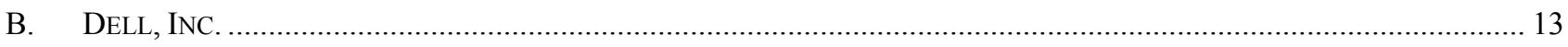

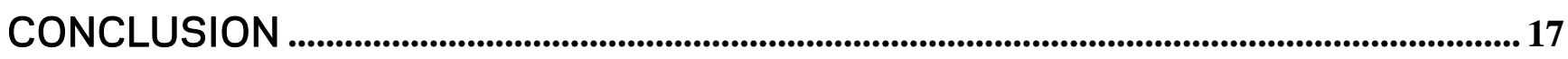

REFERENCES .................................................................................................................................. 19 


\section{Overview}

Accounting is often criticized for omitting intangible assets from the balance sheet. With value in firms of today flowing less from tangibles assets and more from so-called intangibles - brands, distribution systems, supply chains, "knowledge capital," "organization capital" - accounting is seen as remiss, with high price-to-book ratios as evidence. The remedy often proposed involves booking these intangible assets to the balance sheet.

This paper makes the point that accounting is not necessarily deficient in omitting intangible assets from the balance sheet: there is also an income statement, and the value of intangible (and other) assets can be ascertained from the income statement. For example, although The Coca-Cola Company does not report its brand asset on its balance sheet (and trades about five time book value), earnings from the brand flows through its income statement. Thus the firm is readily valued from its earnings; the income statement remedies the deficiency in the balance sheet. Accordingly, accounting that calls for the recognition of "intangible assets" on the balance sheet may be misconceived.

The paper explores the case where the income statement perfectly corrects for a deficient balance sheet, and the case where it does not. It then explores whether, in the latter case, accounting in the balance sheet - by capitalization and amortization of intangible assets or carrying them at fair value - could remedy the deficiency in the income statement (or makes it worse). The investigation involves an analysis and valuation of Microsoft Corporation and Dell, Inc., two companies presumed to possess a good deal of "intangibles assets."

The paper is instructive, not only to those concerned with accounting issues, but also to analysts attempting to value firms with assets missing from the balance sheet. It shows how to handle the accounting information in valuation and how to deal with the perceived deficiencies, real or imagined, with respect to intangible assets. In the case of Microsoft and Dell, the reader can observe at how close one comes to their market valuation by using valuation techniques that use accounting information currently provided by GAAP. 


\section{Introduction}

Many commentators view the omission of "intangible assets" from balance sheets as a glaring deficiency. They ask: How can accountants report a balance sheet that omits important assets like brands, distribution and supply chains, knowledge, human capital, and organization capital, particularly when value in modern firms comes more from these assets than from the tangible assets on the balance sheet? The complaint reached a crescendo during the 1990s as technology and internet firms identified with these types of "assets" came to the market with high price-to-book ratios that were attributed to missing assets on the balance sheet. While a diminuendo followed as the perceived intangible assets for many of these firms seemingly evaporated, the accounting for intangible assets continues as a significant research area. Indeed, the current trend towards booking more value to the balance sheet with fair value accounting involves many of the same issues.

This paper provides a perspective that I hope is not only helpful to those grappling with accounting issues but also to analysts who use financial statements to value firms with so-called intangible assets. The main point of the paper simply reminds us that accounting reports not only a balance sheet but also an income statement. The value of assets can be ascertained from the income statement as well as a balance sheet, so the issue of accounting for intangible assets is not necessarily a balance sheet problem. Indeed, there is no accounting problem if the income statement informs about the value. If it does so imperfectly, the research question involves asking if and how accounting for intangible assets in the balance sheet can ameliorate the problem. Calls for recognition of intangible assets on balance sheets may be misconceived; they fail to understand the structure of accounting under which articulated income statements and balance sheets work together to indicate firm value, and each statement can correct for the deficiencies in the other.

Before expanding on this theme, the paper makes a number of preliminary points that bear on how accounting might handle intangible assets. 


\section{Preliminary Points}

1. "Intangible asset" is a speculative notion. Intangible assets differ from tangible assets not just because they lack physical appearance but also because they are not identifiable such that contracts can be written on them for delivery. Explicit legal rights like patents and copyrights, and possibly brands, are exceptions (and these are booked to the balance sheet if purchased, as with any other asset), but "customer relationships," "organization capital," "knowledge assets," "human capital," and the like, are not specific enough for a market price ever be observed for them. A conjectured value of a conjectured asset that can never be validated with a market price is inherently speculative; value is in the mind of the beholder. This was so for the "intangible assets" conjectured in the 1990s bubble for which there was no subsequent manifestation. Accounting runs into trouble when speculative, conjectured values enter the financial statements, more so when the asset's existence itself is conjectural. Indeed, the term, "intangible asset" can just be a cover for speculation or even fantasy; the existence of assets can be promoted simply by developing attractive language.

In the speculative 1920s, accountants wrote up asset values in balance sheets for perceived value, but woke to the crash of 1929 accused of "putting water in the balance sheet." The subsequent creation of the Securities and Exchange Commission in the United States led to a 60 year regime where such accounting was a no-no. This outlook was reinforced by fundamental analysts of the time, Benjamin Graham and his adherents. Graham followed a dictum in investing: separate what you know from speculation and anchor on what you know. To the accountants: Don't put speculation into the financial statements; tell me what you know - what I can anchor on - but leave the speculation to me, the analyst. The accountant reports what he or she knows from transactions: if an (intangible) asset is identified in a transaction, book it, but do not book it in response to speculation about its existence.

History repeats. In the speculative 1990s, traditional accounting - derided as accounting "for the industrial age" where value was said to have come from tangible assets - came under challenge, accused of failing to adapt to the "information age" (where value is said to come from intangible assets). But this time accounting authorities largely stood firm against water in the balance sheet. With the bursting of the 1990s bubble and the erosion of market value attributed to intangible assets, "industrial age accounting" now looks sensible; waiting until a firm makes a sale to add value to the balance sheet is not such a bad idea after all. It's what we know, as evidence of value. (The point should be considered by those advocating more fair value accounting in the balance sheet.) 
Those who advocated intangible asset accounting in the 1990s often referred to the high price-to-book ratios as justification. Graham, I think, would turn in his grave. For the fundamentalist, accounting serves to inform about the prices of firms. It should be developed independently of prices, not inferred from prices. Only then can accounting challenge prices. In the fundamentalists' view, accounting should challenge entrepreneurs, management, and analysts who claim that firms possess intangible assets.

2. "Intangible assets" involve using assets jointly. Most intangible assets are not stand-alone assets that can be valued on a balance sheet independently of other assets; rather, their value comes from producing cash flow streams jointly with other assets. Brands, distribution networks, and customer relationships work together to produce value at the Coca Cola Company, and they cannot work without tangible assets such as delivery trucks and bottling plants. "Knowledge capital" is employed with productive processes, marketing, and management, and cannot work without tangible assets. "Organization capital" involves the organization of assets to be used jointly. Indeed, it is the firm that is the asset; the firm is an organization of assets designed to gain competitive advantage, and the entrepreneurial idea that translates to a business plan for organizing the assets is the source of value. Listing an intangible asset on a balance sheet as separately identified is suspect, let alone putting a separate dollar number on it.

The point, of course, applies to all assets on the balance sheet apart from those (like cash and near-cash assets) with separable value (whose liquidation does not affect the value of the remaining assets). Totaling dollar numbers for assets separately listed ("total assets") cannot report joint value. The balance sheet is not a place to report the value of intangible assets or indeed tangible assets. ${ }^{1}$ Recording intangible assets at historical cost, as with tangible assets, is an open issue to which we will return.

\footnotetext{
${ }^{1}$ The statement implicitly criticizes fair value accounting for non-separable individual assets and liabilities that are used jointly. But it also provides an explanation of why separable assets, like marketable securities, could be fair valued. See CEASA's White Paper No. 2, Nissim and Penman (2008) for elaboration.
} 


\section{Main Point: There is also an Income Statement}

If it is impossible to get a summary value number from the balance sheet, is accounting information hopeless for inferring the value of intangible assets? No; there is also an income statement. Even though intangible assets are missing from the balance sheet, earnings from intangible assets flow through the income statement. Value can be established by measuring the asset value directly but also by capitalizing the earnings from the asset. For example, the value of a stand-alone rental building can be ascertained from the market price of the building (a stock valuation) or from the rents that the business yields (a flow valuation). When one cannot determine a stock valuation (a balance sheet valuation), one turns to the flow (an income statement valuation). The value of Coca Cola's brand is not on the income statement, but earnings from the brand are in the income statement. Even with a price-to-book of about 5 because of the missing brand asset in the balance sheet, the Coca-Cola Company is readily valued from its income statement. ${ }^{2}$

There is another important point in turning to the income statement. While the balance sheet cannot yield a summary number that reports the value of using assets jointly, the income statement does (at least in principle): earnings is the accounting measure of value added from employing tangible assets along with entrepreneurship, brands, knowledge, organizational capital, and so on. This is the brilliance of accounting: rendering a performance measure from organizing assets under a business plan. With this summary measure, there is no need to identify intangible assets (or even to ask if they exist); one just observes earnings generated by the business plan.

The point that earnings give the value of intangible assets is implicitly acknowledged in statements of those who claim the existence of intangible assets. Speculators in the 1990s pointed to price-to-book ratios, but writers on intangible assets often point to earnings performance to infer those assets. A recent paper on "Organization Capital” by Lev, Radhakrishnan, and Zhang (2009) is an example. In the paper, "organization capital" is attributed to Wal-Mart, Microsoft, Southwest Airlines, Intel, Dell, and others because these firms have had very good earnings performance. Indeed, the paper estimates the value of "organization capital" from sales and expenses in the income statement. One of course seeks to understand the source of good performance, but attributing earnings performance to "organization capital" is by fiat, without cause and effect demonstrated; one is simply observing firm performance as reported in earnings, whatever the cause, and calling it something else.

\footnotetext{
${ }^{2}$ See Penman (2010), p. 500 and the Appendix B to CEASA White Paper No. 2, Nissim and Penman (2008) for a demonstration.
} 
One thinks usefully of identifying assets with ex ante value, capable of producing future earnings, not something after the fact that attributes ex post performance to a conjectured asset. One would be reluctant to claim that intangible assets existed when Wal-Mart, Dell, and so on were start ups or if they had proceeded to make losses. Indeed, while commentators in the 1990s assailed "industrial age accounting" for ignoring the intangible assets of internet stocks, the derided accounting reported serial losses for these firms that turned out to predict their demise. These firms failed; negative earnings were an indication of the absence of intangible assets. The accounting played its role of challenging the speculators.

Some formality follows to crystallize these ideas. 


\section{The Income Statement Mitigates Poor Balance Sheets}

In what follows, the analyst is viewed as valuing equity, but the ideas apply to any asset, in particular the firm (enterprise) with so-called intangible assets. (Value of the firm = Equity value + Value of Net Debt.)

The balance sheet approach to valuation infers value from book value on the balance sheet:

$$
\text { Value }_{t}={\text { Book } \text { Value }_{t}}
$$

Accordingly, balance sheet accounting attempts to construct balance sheets that are indicative of value. Such accounting and valuation typically works for cash equivalents but not for business assets and equity value, for reasons above. However, if one expects no subsequent earnings growth, value can also be inferred by capitalizing forward earnings:

$$
\text { Value }_{t}=\frac{\text { Expected Earnings }_{t+1}}{r}
$$

Here $r$ is the required return. ${ }^{3}$ If current earnings are a sufficient indicator of forward earnings (because there is no expected earnings growth), ${ }^{4}$

$$
\text { Value }_{t}=\frac{\text { Earnings }_{t}}{r}
$$

A core accounting concept takes the balance sheet out of the picture: the cancelling error property. Provided that earnings are comprehensive (clean-surplus) earnings, it is always true that

$$
\text { Stock Return } \mathrm{t}_{\mathrm{t}+1}=\mathrm{P}_{\mathrm{t}+1}+\mathrm{d}_{\mathrm{t}+1}-\mathrm{P}_{\mathrm{t}}=\text { Earnings }_{\mathrm{t}+1}+\left(\mathrm{P}_{\mathrm{t}+1}-\mathrm{B}_{\mathrm{t}+1}\right)-\left(\mathrm{P}_{\mathrm{t}}-\mathrm{B}_{\mathrm{t}}\right)
$$

\footnotetext{
${ }^{3}$ Balance sheet valuation and income statement valuation are modeled in Ohlson and Zhang (1998). The Ohlson (1995) valuation model is a weighted average of the two.

${ }^{4}$ Retention that adds growth can be accommodated.
} 
For an equity investment, $\mathrm{P}$ is equity price, $\mathrm{B}$ is the book value of equity, and $\mathrm{d}$ is dividends, but the equation applies to the return, earnings, and book value for any asset. ${ }^{5}$

This equation relating returns to earnings says that omission of value from the balance sheet does not matter if the error on the balance sheet, $\mathrm{P}-\mathrm{B}$, at the end of an accounting period is the same as that in the beginning; the errors cancel. In this case, the return equals earnings and, as value is always equal to the expected stock return capitalized at the rate, $r$ (under the no-arbitrage condition), value is also equal to capitalized expected earnings. Valuation tolerates accounting error in the balance sheet if that error is constant.

We teach the cancelling error property in introductory accounting courses by pointing out that it does not matter whether one capitalizes $R \& D$ expenditure (and subsequently amortizes it) or expenses it immediately, provided there is no growth in R\&D expenditure. ${ }^{6}$ Even though it is perceived to be "wrong" to leave R\&D investment off the balance sheet, the balance sheet errors from expensing immediately cancel, leaving earnings unaffected. More generally, the omission of assets from the balance sheet is mitigated by the income statement and cancelling errors. ${ }^{7}$

\footnotetext{
${ }^{5}$ This equation first appears in Easton, Harris, and Ohlson (1992), but textbooks of old used to discuss the cancelling error property.
} The equation is derived as follows. The "clean-surplus" equation forces the articulation of earnings, book value, and net dividends:

$$
\mathrm{B}_{\mathrm{t}+1}=\mathrm{B}_{\mathrm{t}}+\text { Earnings }_{\mathrm{t}+1}-\mathrm{d}_{\mathrm{t}+1}
$$

Substituting $d_{t+1}=$ Earnings $_{t+1}-\left(B_{t+1}-B_{t}\right)$ into the stock return, $P_{t+1}+d_{t+1}-P_{t}$,

$$
\text { Stock Return } \mathrm{t}_{\mathrm{t}+1}=\text { Earnings }_{\mathrm{t}+1}+\left(\mathrm{P}_{\mathrm{t}+1}-\mathrm{B}_{\mathrm{t}+1}\right)-\left(\mathrm{P}_{\mathrm{t}}-\mathrm{B}_{\mathrm{t}}\right) \text {. }
$$

\footnotetext{
${ }^{6}$ The reader can demonstrate this by working through the accounting from investing $\$ 100$ in R\&D each year that generates sales of $\$ 150$ in each of the subsequent three years (say), with the R\&D amortized over three years under the capitalization regime. Once steady state is reached in the balance sheet (constant sales and book values), earnings are the same for both regimes. Penman (2010), Chapter 16 provides an example, and extends the example to the case where there is growth.

${ }^{7}$ The perspective here implicitly criticizes a balance sheet emphasis for financial reporting that is proposed in the FASB and IASB discussion documents on a new conceptual framework. The income statement focus here lies in sharp contrast. For a more detailed discussion on the balance sheet focus, see CEASA's Occasional Paper, Dichev (2007).
} 


\section{Can the Balance Sheet Mitigate Poor Income Statements?}

Having understood that putting an intangible asset on the balance sheet adds nothing when there is no growth in that asset, it follows that recognizing an intangible asset on the balance sheet can only be helpful if there is growth. Again we know from our introductory accounting that, while expensing R\&D does not affect earnings relative to $R \& D$ capitalization when there is no growth in $R \& D$ expenditures, growth in $R \& D$ depresses earnings if the R\&D expenditure is expensed. The stock return-earnings equation (3) says that this introduces a change in premium; that is, errors in the balance sheet do not cancel (the premium over book value widens). The accounting produces error in both book value and earnings; the task of correcting these errors is left to the analyst.

If intangible asset research is to focus on the balance sheet, the question is whether correction of the balance sheet error (by booking intangible assets) mitigates the error in earnings as a basis for valuation. Can accounting resolve the problem, or must it be left to the analyst to add value for intangibles? Below are some issues to consider in pursuing this research question:

1. For the reasons in the preamble, booking the value of intangible assets on the balance sheet is quite doubtful if value comes from using assets jointly. Even if identifiable, any valuation is likely to be speculative.

2. Reporting speculative, fuzzy numbers on the balance sheet can damage earnings as an indicator of value rather than ameliorating the error in earnings. By the clean-surplus relation, earnings is the difference in book value (adjusted for net dividends), so errors in measurement of book value (net assets) is magnified in earnings; the error in earnings is affected by the random errors in both the beginning and ending book value. ${ }^{8}$ (One would strictly be worse off in the no-growth case, by adding error to beginning and ending book values that would otherwise cancel.)

3. If one rules out intangible assets on the balance sheet at estimated (speculative) value, one is left with the question of whether they should be booked at historical cost and then amortized. This is more familiar ground to the accountant and well worth further research. As capitalization makes no difference in the nogrowth case, the issue is whether earnings in the growth case is more informative with capitalization. Here are some considerations:

a. Isolating the cost of intangible assets that are hard to identify (like organizational capital, knowledge capital, and the like) is likely to be difficult. Not only are current earnings affected by any imprecision (as expenses capitalized would otherwise be in earnings), but future earnings will be affected by the amortization of

\footnotetext{
${ }^{8}$ Peasnell (2006) makes this point with respect to fair value accounting.
} 
fuzzy numbers. The specter of earnings management - shifting expenses to the balance sheet from the income statement - arises. Capitalization of observable expenditures on R\&D and brand building through advertising is more straightforward. Resolving when and how expenditures on non-tangible assets might be capitalized is a promising area of research.

b. Even if historical cost can be identified with integrity, establishing an amortization schedule would typically be quite speculative. Unlike purchased patents and copyrights that have definite lives and tangible assets with estimable lives, the life of more sublime intangible assets is very uncertain, as is the pattern of economic benefits for matching costs against revenue over time. Fuzzy amortization expense may well destroy earnings as a basis for valuation and thus make accounting less informative about value. The experience with amortizing purchased goodwill (before the new accounting that requires impairment) speaks to the issue. Analysts routinely added back amortization expense, seen as arbitrary, implicitly rejecting accountants' attempts to deal with intangible valuation in this way. The analysts said: leave the speculation to us. Solving the amortization issue with impairment testing (as with the new requirements for goodwill), is fraught with difficulties. Ascertaining the impaired value of an intangible is problematic, though one could look to triggering events like failure to get government approval for a drug. In general, the experience with one-time charges has been unsatisfactory; they are seen as obscuring the profitability picture and subject to abuse with earnings management. It is an open research question as to whether they improve the ability of earnings to indicate value.

These points aside, the issues around capitalization and amortizing are the most encouraging for accounting research. It is on this point that the Lev, Radhakrishnan, and Zhang (2009) paper is most interesting: their analysis involves capitalizing and amortizing selling, administrative and general expenses (SG\&A) and also an abnormal profit measure. ${ }^{9}$ For identifiable expenditures, research might focus on developing amortization schedules (for R\&D, for example) that captures the economics. That might be feasible in the case of an established firm with a long history of payoffs to R\&D. However, the established firm is likely to report earnings that are quite informative (with canceling errors) under an immediate expensing rule, so changing the accounting may not be effective. For a start-up R\&D firm, where earnings are less informative, the specification of an amortization schedule (and even the assessment of any future benefits at all) is much trickier.

As benefits to intangible assets are so speculative, the accountant might well fall back on the advice of the fundamentalist: Don't put speculation in the financial statements; tell me what you know, but leave the speculation to me, the analyst. The advice says that the accountant has no comparative advantage in handling speculation. That division of labor is assigned to the analyst with his or her deep knowledge of the business and the industry.

\footnotetext{
${ }^{9}$ Kovacs (2004) also finds that treating SG\&A as an asset indicates future benefits.
} 
Accounting is utilitarian, so the accounting research question is one of developing accounting that handles intangible assets in a way that helps rather than hinders the analyst who wishes to value the firm. The standard residual earnings model, expressed in its short form here, explains how an analyst estimates value from book value and earnings. With Earnings $s_{t+1}$ forecast by Earnings ${ }_{t},{ }^{10}$

$$
\text { Value }_{t}=\text { Book Value }_{t}+\frac{\text { Earnings }_{t}-\left(r . \text { Book Value }_{t}\right)}{r-g}
$$

The growth rate here, $g$, is the expected growth rate for residual earnings (in the numerator) which, in turn, comes from the growth in the book value (net assets) and the earnings they generate. Penman (1997) shows that the growth rate, $g$, is determined (solely) by the errors in the book value and earnings relative to their benchmarks in equations (1) and (2). That is, growth in residual earnings is actually an accounting phenomenon produced by earnings and book value that differ from those which directly indicate value. If the accounting has balance sheet errors (such that value $\neq$ book value) but those errors cancel, as in the stock return equation (3), $g=0$, and the valuation is based solely on earnings. ${ }^{11}$ If in addition to balance sheet errors there are errors in the earnings such that equation (2) does not hold, $g \neq 0$ and the amount of $g$ is determined by the size on the two errors. $^{12}$

Significantly, we observe that analysts in practice forecast earnings and earnings growth. Forecasting is speculation and analysts step in to add speculative growth to the accounting when the accounting is incomplete. The picture is quite consistent with the view of the fundamentalists. Benjamin Graham saw expected growth as

${ }^{11}$ Retention can be accommodated such that Earnings $_{t+1}$ equals Earnings $s_{t}$ plus further earnings expected from retention.

${ }^{11}$ In this case, equation (4) is equivalent to equation (2). Restating equation (4) for $g=0$,

$$
\begin{aligned}
& \text { Value }_{t}={\text { Book } \text { Value }_{t}+\frac{\left[\text { Earnings }_{t}-\left(r \times \text { Book Value }_{t}\right)\right]}{r}}_{r} \\
& ={\text { Book } \text { Value }_{t}}+\frac{\text { Earnings }_{t}}{r}-\frac{r \times{\text { Book } \text { Value }_{t}}}{r} \\
& =\frac{\text { Earnings }_{t}}{r}
\end{aligned}
$$

As this valuation holds in the case of balance sheet errors that cancel, one sees that the introduction of $g$ in equation (4) is due to errors in earnings as well as errors in the balance sheet.

${ }^{12}$ Feltham and Ohlson (1995) show how conservative accounting (that keeps assets off the balance sheet) induces growth in residual earnings. Penman (2010), Chapter 16, has examples showing how growth in investment produces growth in residual earnings when assets are not booked to the balance sheet. 
the most speculative part of a valuation. As an investor he was most careful in handling growth, but he saw it as something to be handled by the analyst, not the accountant. ${ }^{13}$

This picture focuses the research question: can accounting be utilized or modified to supply the $g$ (perhaps through reporting line items that aid additional financial statement analysis) or is the determination of the growth rate for residual earnings best left to the analyst?

What follows are two cases which show how an analyst handles the valuation of firms with intangible assets. The first is Microsoft Corporation, to which commentators attribute intangible assets in large doses. The second is Dell Inc., a firm to which a significant "organization capital" asset is often attributed because of its unique "direct-to-customer" diversified supply chain.

\footnotetext{
${ }^{13}$ See Graham (1973), pp. 315-316 and Penman (2006).
} 


\section{Handling Intangible Assets with Accounting Information}

\section{A. Microsoft Corporation}

After publishing its annual report for fiscal-year ending June, 2008, Microsoft traded at \$25 per share or $\$ 228,775$ million. With book value of $\$ 36,286$ million, the market saw considerable value, $\$ 192,489$ million, missing from the balance sheet (the price-to-book ratio is 6.3). The book value of $\$ 36,286$ million was made up of $\$ 12,624$ million of net operating assets (enterprise book value) and \$23,662 million of cash and near-cash investments (and no financing debt). The latter are separable, marked to market, and are typically considered to be carried at their value. The income statement for 2008 reported interest income on the cash and near-cash assets of $\$ 846$ million (after an allocation of tax) and after-tax income from the business of $\$ 16,835$ million, for total net income of $\$ 17,681$ million.

These accounting numbers are summary numbers from the financial statements and presumably one would gather more information with a full financial statement analysis. But how far can we go towards a valuation with just these few numbers? Applying residual earnings valuation as if there were no expected growth (no errors in earnings), Value of equity $=$ Enterprise value + Value of cash $=$

$$
\text { Enterprise Book Value }_{2008}+\frac{\text { Expected Enterprise Residual Income }_{2009}}{r}+\text { Cash }_{2008}
$$

The risk-free rate at the time was about 4 percent and finance web sites were giving Microsoft a beta of about 1.0. With a typical risk premium for a beta of 1.0 of 5 percent, a reasonable required return for the enterprise (the weighted-average cost of capital, WACC) is 9 percent. The equity value, calculated from the summary income statement and balance sheet numbers is (in millions of dollars),

$$
\text { Value of Equity }=12,624+\frac{16,835-(0.09 \times 12,624)}{0.09}+23,662=210,718 \text { or } \$ 23.03 \text { per share. }
$$

Note that the valuation forecasts 2009 enterprise income as being the same as that reported for 2008 and the capitalization at 9 percent forecasts a perpetuity at that level. Thus we are only using information in the financial statements, strictly. One can quibble about the appropriate required return, but the point is clear: While 
considerable value is missing in the balance sheet, the accounting that includes earnings explains almost all the value that the market sees. Of course, this is not to dismiss the research question: can accounting be designed to do an even better job? But is does serve to say that accounting, as practiced, does not do as poor a job as those who insist on intangible asset accounting imply.

Of course, the market price could be a misprice, so the validation is not emphatic. But history would suggest that the accounting numbers would have provided a strong challenge to mispricing: In the bubble years when Microsoft was trading at up to $\$ 60$ (on a post-split basis) and very high multiples, the accounting valuation was much lower than the market price. Rather than the market price suggesting that the accounting was ignoring intangible assets, the accounting (which reflected the value of intangible assets through earnings) would have suggested that the market was mispricing those assets. While after-the-fact observations are dangerous, subsequent experience suggests that investors who shunned intangible asset stocks such as Microsoft, Cisco Systems, Intel, Dell, and the like in the late 1990s fared considerably better than those who purchased the stocks because they had "intangible assets".

The valuation above can be criticized because it does not incorporate the expected growth rate in equation (4). But the core question is whether better accounting can supply this or whether it is best left to the analyst. It is a fascinating question, because (as noted) growth is an accounting phenomenon due to errors in earnings and book value. Note, however, that financial reports do not report just earnings and book values; they also report more detailed financial information in line items and, over time, historical sales, earnings, and book value growth rates. This information can be exploited with financial statement analysis. ${ }^{14}$ For a market price of $\$ 25$ for Microsoft, the growth rate implied (that reverse engineers the residual earnings model) is 0.84 percent. The analyst challenges this implied growth rate using further financial statement analysis and other information.

\section{B. Dell, Inc.}

Dell, the computer manufacturer, is said to have valuable "organization capital". Are its financial statements deficient because this nominated asset is not on the balance sheet? Below is the balance sheet for Dell for fiscal year 2008, reformulated to separate assets in the business from the net financial assets consisting of cash and near-cash assets less financing debt.

\footnotetext{
${ }^{14}$ See Penman (2010), Chapter 14 for financial statement analysis that elicits growth rates for valuation. An example there (and in Appendix B of Nissim and Penman 2008) shows how the historical sales growth rate for Coca-Cola Company yields a valuation close to the market price.
} 


\begin{tabular}{|c|c|c|c|c|}
\hline \multicolumn{5}{|c|}{$\begin{array}{c}\text { DELL, INC. } \\
\text { Comparative Balance Sheet, 2008, } \\
\text { Reformulated } \\
\text { (in millions of dollars) }\end{array}$} \\
\hline & & 2008 & & 2007 \\
\hline \multicolumn{5}{|l|}{$\begin{array}{l}\text { Enterprise Book } \\
\text { Value: } \\
\text { Enterprise Assets }\end{array}$} \\
\hline Working cash & & 40 & & 40 \\
\hline Accounts receivables & & 5,961 & & 4,622 \\
\hline Financing receivables & & 2,139 & & 1,853 \\
\hline Inventories & & 1,180 & & 660 \\
\hline $\begin{array}{l}\text { Property, Plant and } \\
\text { Equipment }\end{array}$ & & 2,668 & & 2,409 \\
\hline Goodwill & & 1,648 & & 110 \\
\hline Intangible assets & & 780 & & 45 \\
\hline \multirow[t]{2}{*}{ Other assets } & & $\underline{3,653}$ & & $\underline{3,491}$ \\
\hline & & 18,069 & & 13,230 \\
\hline \multicolumn{5}{|l|}{ Enterprise Liabilities } \\
\hline Accounts payable & 11,492 & & 10,430 & \\
\hline Accrued liabilities & 4,323 & & 5,141 & \\
\hline $\begin{array}{l}\text { Deferred service } \\
\text { revenue }\end{array}$ & 5,260 & & 4,221 & \\
\hline Other liabilities & $\underline{2,070}$ & 23,145 & $\underline{647}$ & 20,439 \\
\hline $\begin{array}{l}\text { Net Enterprise } \\
\text { Assets }\end{array}$ & \multicolumn{3}{|c|}{ Net Enterprise } & $-7,209$ \\
\hline \multicolumn{5}{|l|}{ Net Financial Assets } \\
\hline Cash Equivalents & 7,724 & & 9,506 & \\
\hline $\begin{array}{l}\text { Short-term } \\
\text { investments }\end{array}$ & 208 & & 752 & \\
\hline \multirow[t]{2}{*}{ Long-term investments } & $\underline{1,560}$ & & $\underline{2,147}$ & \\
\hline & 9,492 & & 12,405 & \\
\hline Short-term borrowing & -225 & & -188 & \\
\hline Long-term debt & -362 & & -569 & \\
\hline Redeemable stock & -94 & $\underline{8,811}$ & -111 & $\underline{11,537}$ \\
\hline $\begin{array}{l}\text { Common } \\
\text { Shareholders' Equity }\end{array}$ & & $\underline{\underline{3,735}}$ & & $\underline{\underline{4,328}}$ \\
\hline
\end{tabular}


Trading at $\$ 20$ per share or an equity market capitalization of $\$ 41,200$ million at the time, the market attributed considerable value to Dell over the book value of \$3,735 million (a price-to-book of 11). The missing balance sheet value could readily be attributed to the enterprising way Dell organizes its business (direct-tocustomer delivery, just-in-time inventory, outsourcing of production, and innovative supply chains). But putting an "organization capital" asset on the balance sheet could be redundant: the balance sheet, presented in the form here, actually highlights these features. Relative to $\$ 61.1$ billion in sales, accounts receivable is low (direct-tocustomers yields cash in advance), inventory is low (just-in-time), and property, plant and equipment is low (outsourcing). The low enterprise asset values mean that shareholders need invest less to get value. But the big feature of the balance sheet is the negative net enterprise assets, - \$5,076 million in 2008. This negative number is due not only to the low investment in assets, but to the large enterprise liabilities. In managing its supply chain, Dell is able to get suppliers to accept deferred payment (so that accounts payable and accrued expenses are high), and attracts customers to pay in advance (producing deferred revenues).

The negative net enterprise assets means that there is even more value (from the business) missing from the balance sheet than the 11 price-to-book ratio would suggest; the shareholders equity is positive only because Dell holds $\$ 8,811$ million in net financial assets. Does this make the accounting even more deficient? No; because there is also an income statement. That statement reports enterprise income (after tax) of $\$ 2,618$ million. Calculating residual income from the enterprise (value added over book value at the beginning of the year) using a required return of 10 percent,

Residual Income $=2,618-(0.10 \times-7,209)=3,338.9$ (in millions of dollars $)$

Dell's residual income is actually larger than its income. This is because Dell adds value with earnings of $\$ 2,618$ million, but also from organizing its business with negative net enterprise assets. The value of the organization asset is reflected in the accounting. That organization means that Dell effectively runs a float and that float means that shareholders, rather than investing in the business, can withdraw from the business and invest elsewhere: rather than investment being charged at the required return to reduce residual income, the component of the residual income calculation, $\$ 720.9=-(0.10 \times-7,209)$ million, is the value that shareholders add from investing the float at 10 percent. (Dell's large, yearly stock repurchases are in part the flow to shareholders out of this float.)

Incorporating the residual income into a valuation with no growth,

Value of Equity $=8,811-5,076+=37,124$ million or $\$ 18.02$ per share. 
This is lower than the market price of $\$ 20$, but the point is that much of the value of "organization capital" in the market price is in the accounting. The missing value in the accounting must come from expected growth, and that growth (in residual income) must come from growth in enterprise income or growth in the float from the way the business is organized. The challenge for research into the accounting for intangibles is to ask whether the extra $\$ 2$ in value can be elicited by better accounting of whether it should be left to the analysts to speculate about. 


\section{Conclusion}

This paper challenges both the perception that accounting ignores the value of intangible assets and the prescribed remedy of booking intangible assets to the balance sheet. The paper explains how rich accounting can be, even with the omission of intangible assets from the balance sheet. The reason is that there is also an income statement that remedies deficiencies in the balance sheet. The examples with Microsoft and Dell, two companies to whom "intangible assets" are often attributed, demonstrate that accounting, handled appropriately, is not backward looking, but reports forward looking information from which value can be estimated.

Of course, income statements may not always be as rich as those for seasoned firms like Microsoft and Dell. Indeed, for a start-up reporting losses, the accounting can be quite uninformative. But one has to ask whether there is an accounting solution that solves the problem. A start-up is the most speculative of firms, possibly with no product developed yet from its R\&D, no government approval for its drug, and no sales. Guessing the likely outcome for these firms and putting it into the balance sheet (or even capitalizing expenditures) would be very speculative accounting. I tell my students who ask how to value a start-up biotech: Go and get a PhD in biochemistry; it is not an issue that accounting can solve.

The paper aims not to discourage research into accounting for intangible assets, but to put it in perspective. As with any accounting research, the researcher needs to start with an understanding of how accounting works to indicate value, and focus on the balance sheet alone is misconceived. The issue of capitalization and amortization of expenditures on intangible assets is very much alive, but developing amortization schedules that improve rather than damage earnings is a challenge.

Research might also focus on financial statement analysis - the analysis of balance sheet and income statement line items - and combining that analysis with other non-accounting information to forecast earnings growth. In so doing, research helps the analyst to whom the task of speculation falls. The Lev, Radhakrishnan, and Zhang (2009) paper is really a financial statement analysis utilizing sales, expenses, and property, plant, and equipment, along with other information on employees and peer performance to forecast future sales and operating income growth. The financial statement analysis looks promising. However, placing a label "organization capital" on the financial statement analysis measure extracted adds little, for no cause and effect is documented.

Intriguingly, though, the Lev, Radhakrishnan, and Zhang (2009) measure involves some capitalization and amortization (of SG\&A expense). Capitalizing and amortizing is an accounting issue, not an analysis issue. 
Isolating the contribution of this accounting to the forecast of growth (from financial statement analysis components of the measure) would be very helpful to those involved in research into accounting for intangibles.

As most of the research on intangibles focuses on the valuation of intangible assets, this paper takes a valuation approach for evaluating the accounting issues. There may well be other issues (stewardship of assets, control, and planning) where the accounting for intangibles should be approached differently. 


\section{References}

Dichev, I. D. 2007. On the Balance Sheet-Based Model of Financial Reporting. CEASA Center for Excellence in Accounting and Security Analysis, Columbia Business School, Occasional Paper Series (September), available at https://www4.gsb.columbia.edu/null? exclusive=filemgr.download\&file id=10.

Easton, P., T. Harris, and J. Ohlson. 1992. Accounting earnings can explain most of security returns: The case of long-event windows. Journal of Accounting and Economics 15: 119-142.

Feltham, G., and J. Ohlson. 2005. Valuation and clean surplus accounting for operating and financial activities. Contemporary Accounting Research 12: 689-731.

Graham, B. 1973. The Intelligent Investor, 4th rev. edition. New York: Harper and Row.

Kovacs, E. 2004. The future benefits in selling, general and administrative expenses. Unpublished Ph.D. dissertation, Columbia University.

Lev, B., S. Radhakrishnan, and W. Zhang. 2009. Organization capital. Abacus, forthcoming.

Nissim, D. and S. Penman. 2008. Principles for the Application of Fair Value Accounting. CEASA Center for Excellence in Accounting and Security Analysis, Columbia Business School, White Paper No. 2 (April), available at http://www4.gsb.columbia.edu/null? \&exclusive=filemgr.download\&file id=3822.

Ohlson, J. 1995. Earnings, book values and dividends in equity valuation. Contemporary Accounting Research 11 (Spring): 661-687.

Ohlson, J., and X. Zhang. 1998. Accrual accounting and equity valuation. Journal of Accounting Research 36 (Supplement): 85-111.

Peasnell, K. 2006. Institution-specific value. BIS Working Paper No. 210.

Penman, S. 1997. A synthesis of equity valuation techniques and the terminal value calculation for the dividend discount model. Review of Accounting Studies Accounting Research 2: 303-323.

Penman, S. 2006. Handling valuation models. Journal of Applied Corporate Finance 18: 48-55.

Penman, S. 2010. Financial Statement Analysis and Security Valuation, 4th edition. New York: The McGrawHill Companies. 


\section{People at the Center}

Trevor Harris, The Arthur J. Samberg Professor of Professional Practice, Columbia Business School; Former Vice Chairman, Morgan Stanley; Co-Director, CEASA

Stephen Penman, George O. May Professor of Accounting, Columbia Business School; Co-Director, CEASA

Svetlana Juster, Associate Director of Research, Columbia Business School, CEASA

\section{Advisory Board}

Chair

Arthur Levitt, Jr., 25th Chairman of the United States Securities and Exchange Commission (1993-2001), Senior Advisor, The Carlyle Group

$\underline{\text { Board Members }}$

Philip D. Ameen, Former Vice President and Comptroller, General Electric Company

Mark J.P. Anson, President and Executive Director of Investment Services, Nuveen Investments

John H. Biggs, Former Chairman and Chief Executive Officer, TIAA-CREF

Richard Carroll, Chief Accountant, IBM

J. Michael Cook, Retired Chairman and CEO, Deloitte \& Touche LLP

Sir Howard J. Davies, Director, London School of Economics and Political Science; Former Chair, Financial Services Authority, United Kingdom

Peter Fisher, Managing Director, BlackRock

Sallie Krawcheck, Former Chairman and CEO of Citi Global Wealth Management, Citigroup

David F. Larcker, Professor of Accounting, Stanford University, Graduate School of Business

Carol J. Loomis, Senior Editor-at-Large, FORTUNE Magazine

Robert J. Swieringa, Anne and Elmer Lindseth Dean Emeritus and Professor of Accounting, S.C. Johnson Graduate School of Management, Cornell University; Former Member, Financial Accounting Standards Board 
.1. COLUMBIA UNIVERSITY in the City of New York

(c) 2009 Center for Excellence in Accounting and Security Analysis 